\title{
Detection of choroidal hypoperfusion in giant cell arteritis using swept-source
} optical coherence tomographic angiography \\ ${ }^{3}$ Harvard Retinal Imaging Lab \\ WA

\section{Corresponding author:} \\ Eric D. Gaier, MD, PhD \\ Pediatric Neuro-Ophthalmology Service \\ Boston Children's Hospital \\ Harvard Medical School \\ 300 Longwood Ave \\ Boston, MA 02115 \\ Phone: 617-355-6401 \\ Email: eric.gaier@childrens.harvard.edu
}

Authors: $\quad$ Edward S. Lu, BA ${ }^{1,2,3}$, Amy Yuan, MD ${ }^{4}$, Devon A. Cohen, MD ${ }^{1,2}$, Raviv Katz, BS ${ }^{1,2,3}$, John B. Miller, $\mathrm{MD}^{1,2,3}$, Eric D. Gaier, $\mathrm{MD}, \mathrm{PhD}^{1,2,5,6^{*}}$

Affiliations: $\quad{ }^{1}$ Department of Ophthalmology, Massachusetts Eye and Ear Infirmary, Boston, MA

${ }^{2}$ Department of Ophthalmology, Harvard Medical School, Boston, MA

${ }^{4}$ Department of Ophthalmology, University of Washington School of Medicine, Seattle,

${ }^{5}$ Department of Ophthalmology, Boston Children's Hospital, Boston, MA

${ }^{6}$ Picower Institute for Learning and Memory, Department of Brain and Cognitive Sciences, Massachusetts Institute of Technology, Cambridge, MA

Financial support:

JBM: Lions Clubs International Foundation grant 530125.

EDG: NIH K08 EY030164, Children's Hospital Ophthalmology Foundation The sponsor or funding organization had no role in the design or conduct of this research.

Financial Disclosures:
ESL, AY:
JBM:
None
EDG:
Alcon, Zeiss, Sunovion, Allergan, Genentech
Luminopia, Inc (scientific advisor, equity, patent), Stoke Therapeutics, Inc (consultant)

Running head: Choroidal hypoperfusion in giant cell arteritis using OCTA

Key words: $\quad$ ischemic optic neuropathy, giant cell arteritis, optical coherence tomographic angiography, fluorescein angiography

\footnotetext{
Abbreviations: swept-source optical coherence tomographic angiography (SS-OCTA), fluorescein angiography (FA), giant cell arteritis (GCA), arteritic anterior ischemic optic neuropathy (AAION), superficial capillary plexus (SCP), deep capillary plexus (DCP), choriocapillaris (CC), age-related macular degeneration (AMD), central serous chorioretinopathy (CSC), spectral-domain (SD), platelet (PLT), erythrocyte sedimentation rate (ESR), polymyalgia rheumatica (PMR), C-reactive protein (CRP)
} 
medRxiv preprint doi: https://doi.org/10.1101/2021.05.21.21257605; this version posted May 26, 2021. The copyright holder for this preprint (which was not certified by peer review) is the author/funder, who has granted medRxiv a license to display the preprint in perpetuity.

All rights reserved. No reuse allowed without permission.

46 ABSTRACT

47 Objective: To determine whether swept-source optical coherence tomographic angiography (SS-

48 OCTA) can demonstrate choroidal perfusion abnormalities seen on fluorescein angiography (FA)

49 in giant cell arteritis (GCA).

50 Design: Observational case series.

51 Participants: Six eyes of 3 patients with bilateral ischemic optic neuropathy secondary to GCA,

52 and one control patient without ocular involvement from biopsy-confirmed GCA.

53 Methods: En face SS-OCTA (DRI OCT Triton, Topcon, Tokyo, Japan) and FA centered on the

54 macula were obtained at presentation. SS-OCTA was segmented into superficial and deep retinal

55 capillary plexuses and the choriocapillaris laminae. SS-OCTA images were independently

56 analyzed for perfusion abnormalities and compared with corresponding FA images.

57 Main Outcome Measures: Correspondence of choroidal angiographic abnormalities on SS-

58 OCTA and FA.

59 Results: SS-OCTA showed decreased angiographic signal within the choriocapillaris in 5/6 eyes

60 and corresponded to hypoperfusion abnormalities on FA in similar geographic distributions in

$615 / 5$ eyes. SS-OCTA also showed dilation of the deep retinal capillary plexus overlying the area

62 of choroidal hypoperfusion in one eye. In the one eye without angiographic signal abnormalities

63 on SS-OCTA, no perfusion changes were noted on FA. One control patient without ocular

64 involvement from biopsy-confirmed GCA did not show choroidal perfusion changes on SS-

65 OCTA or FA.

66 Conclusions: This case series demonstrates comparability between SS-OCTA and FA in

67 detection and characterization of choroidal hypoperfusion secondary to GCA. As a rapid and 
medRxiv preprint doi: https://doi.org/10.1101/2021.05.21.21257605; this version posted May 26, 2021. The copyright holder for this preprint (which was not certified by peer review) is the author/funder, who has granted medRxiv a license to display the preprint in perpetuity.

All rights reserved. No reuse allowed without permission.

68 non-invasive tool, SS-OCTA may serve as a viable alternative to FA in the diagnostic evaluation 69 of GCA.

70

71 
medRxiv preprint doi: https://doi.org/10.1101/2021.05.21.21257605; this version posted May 26, 2021. The copyright holder for this preprint (which was not certified by peer review) is the author/funder, who has granted medRxiv a license to display the preprint in perpetuity.

All rights reserved. No reuse allowed without permission.

\section{INTRODUCTION}

73 Giant cell arteritis (GCA) is an immune-mediated vasculitis of medium to large sized arteries

74 that predominantly affects adults over the age of 50 with high morbidity and mortality if

75 untreated. ${ }^{1,2}$ GCA affects the short posterior ciliary arteries supplying the prelaminar and laminar

76 portions of the optic nerve head, resulting in acute vision loss and pallid nerve oedema

77 characteristic of arteritic anterior ischemic optic neuropathy (AAION). ${ }^{3,4}$ Other hallmark

78 symptoms of GCA include headache, myalgias, fatigue, fever, weight loss, or jaw claudication.

79 Fluorescein angiography (FA) classically demonstrates delayed or incomplete choroidal filling in

80 the acute phase of GCA. ${ }^{5,6}$

81 Optical coherence tomographic angiography (OCTA), a non-invasive tool for imaging of

82 laminar blood flow, provides high-resolution, three-dimensional segmentation of the

83 chorioretinal microvasculature into the superficial capillary plexus (SCP), deep capillary plexus

84 (DCP) and choriocapillaris (CC). ${ }^{7}$ While FA has historically been the standard imaging modality

85 for chorioretinal vascular pathology, OCTA is a promising alternative to dye-based

86 angiography. ${ }^{8}$ OCTA has been shown to demonstrate choroidal changes in a range of eye

87 conditions including age-related macular degeneration (AMD), central serous chorioretinopathy

88 (CSC), uveitis, and inherited retinal disorders. ${ }^{9}$ Reported OCTA evidence of choroidal

89 hypoperfusion secondary to GCA is currently limited to our previous case series and two case

90 reports. $^{10-12}$

91 We previously reported a series of 4 GCA cases imaged with spectral domain (SD)-

92 OCTA $^{10}$. In 2 cases with choroidal hypoperfusion seen on FA, no corresponding reduction in

93 SD-OCTA signal was seen. Swept-source OCTA (SS-OCTA) allows for increased penetration

94 into the choroid compared to conventional SD-OCTA. ${ }^{13-15}$ We hypothesized that SS-OCTA 
medRxiv preprint doi: https://doi.org/10.1101/2021.05.21.21257605; this version posted May 26, 2021. The copyright holder for this preprint (which was not certified by peer review) is the author/funder, who has granted medRxiv a license to display the preprint in perpetuity.

All rights reserved. No reuse allowed without permission.

95 would demonstrate choroidal perfusion abnormalities apparent on FA in patients presenting with

96 ocular ischemia secondary to GCA.

97

98 METHODS

\section{Subjects}

100 This prospective, observational study was conducted at Massachusetts Eye and Ear and adhered

101 to the tenets of the Declaration of Helsinki and Health Insurance Portability and Accountability

102 Act regulations. Institutional Review Board (IRB)/Ethics Committee approval was obtained.

103 Consent for SS-OCTA imaging and the use of imaging for education, research and publication

104 purposes was obtained from all participants prior to enrolment. Consecutive patients with GCA

105 who underwent imaging with both FA and SS-OCTA at the time of initial presentation between

106 October 2017 and February 2018 were included (Table 1). GCA diagnosis was made based on a

107 positive temporal artery biopsy or clinical features. No patients in this time interval were

108 excluded from the study. All GCA patients had a complete dilated eye examination by an

109 attending neuro-ophthalmologist. Automated static (Humphrey, SITA 24-2 or 30-2) or manual

110 kinetic (Goldmann) perimetry and fundus imaging (Topcon, Tokyo, Japan) were obtained at the

111 initial clinic visit. Demographic and clinical parameters were obtained from the electronic

112 medical record.

\section{Swept-Source OCTA}

115 SS-OCTA images (DRI OCT Triton, Topcon, Tokyo, Japan) were obtained after pupillary

116 dilation in the acute phase of the disease (between 1-4 days of starting corticosteroid therapy). En

117 face SS-OCTA images centered on the macula $(6 \times 6 \mathrm{~mm}$ or $4.5 \times 4.5 \mathrm{~mm})$ were automatically 
medRxiv preprint doi: https://doi.org/10.1101/2021.05.21.21257605; this version posted May 26, 2021. The copyright holder for this preprint (which was not certified by peer review) is the author/funder, who has granted medRxiv a license to display the preprint in perpetuity.

All rights reserved. No reuse allowed without permission.

118 segmented into the SCP $(2.6 \mu \mathrm{m}$ below the internal limiting membrane to $15.6 \mu \mathrm{m}$ below the

119 inner plexiform layer/inner nuclear layer interface), DCP (15.6 to $70.2 \mu \mathrm{m}$ below the inner

120 plexiform layer/inner nuclear layer interface) and CC lamina (0 to $10.4 \mu \mathrm{m}$ below the basement

121 membrane) according to the instrument's default settings. All images were examined for quality,

122 analyzed for perfusion abnormalities, and compared with FA. All scans were of acceptable signal

123 quality and without significant motion artifacts.

124

\section{Fluorescein Angiography}

126 FA images (Spectralis, Heidelberg Engineering, Heidelberg, Germany) were obtained in all cases

127 without complication after pharmacological dilation and administration of $500 \mathrm{mg}$ of IV

128 fluorescein. Timed, choroidal filling videos and early still images (0:25-0:38) were obtained for

129 the better-seeing eye in Case 1 and the symptomatic eyes in Cases 2 and 3. The earliest available

130 individual FA frames were examined and are provided. Brightness and contrast were adjusted in

131 each case to optimize visualization of perfusion defects.

\section{RESULTS}

\section{Case 1}

135 A woman in her late 70s with a history of rheumatoid arthritis presented with sudden vision loss

136 in the right eye (OD) one day prior, with jaw claudication, headache, scalp tenderness and weight

137 loss. On examination, visual acuities were counting fingers OD and 20/30 in the left eye (OS).

138 There was a brisk relative afferent pupillary defect OD and a dense inferior arcuate defect OS on

139 visual field testing (figure 1F; inset). Funduscopic exam revealed pallid optic disc oedema that

140 was circumferential in the right eye and most prominent superonasally in the left eye (figure 1A, 
medRxiv preprint doi: https://doi.org/10.1101/2021.05.21.21257605; this version posted May 26, 2021. The copyright holder for this preprint (which was not certified by peer review) is the author/funder, who has granted medRxiv a license to display the preprint in perpetuity.

All rights reserved. No reuse allowed without permission.

141 F). Inflammatory markers and platelets (PLT) were elevated (ESR 119 mm/hour, CRP 75 mg/L,

142 PLT $748 \mathrm{~K} / \mathrm{uL}$ ). Right temporal artery biopsy was positive. FA demonstrated a large, sharply

143 demarcated area of choroidal filling delay involving the temporal fundus in the right eye (figure

144 1B). The left eye also demonstrated a large, sharply demarcated area of delayed choroidal

145 perfusion centrally that extended inferiorly and temporally (figure 1G). Late frames showed full

146 eventual choroidal filling in these areas and leakage at the optic nerve head in both eyes (not

147 shown). SCP and DCP segmentation of en face SS-OCTA images demonstrated reduced

148 angiographic signal in the perfusion beds of small cilioretinal arteries (figures 1C-D, H-I; green

149 arrows). There was reduction in the SCP density temporally in the right eye, potentially

150 signifying an early consequence of ganglion cell layer and retinal nerve fiber layer atrophy.

151 Segmentation of the CC demonstrated decreased perfusion in the same distribution as the

152 choroidal filling delay observed on FA (figure 1E, J). Relative dilation of the overlying DCP was

153 appreciated in the less severely affected left eye (figure 1I, yellow arrows).

154 The patient was treated with intravenous methylprednisolone and transitioned to an oral

155 prednisone taper. Follow-up exam 6 months later revealed visual acuities of no light perception

156 OD and improvement to 20/25 OS with stable visual field defects.

158 Case 2

159 A woman in her 90s with a chronic macular hole in the right eye presented with one week of

160 night sweats, headaches, scalp tenderness, and jaw claudication without subjective visual loss.

161 Inflammatory markers were markedly elevated (ESR $117 \mathrm{~mm} /$ hour and CRP $298 \mathrm{mg} / \mathrm{L}$ ), and

162 bilateral temporal artery biopsies were positive. Visual acuity was unchanged from baseline

163 (counting fingers OD due to macular hole and 20/30 OS), and a relative afferent pupillary defect 
medRxiv preprint doi: https://doi.org/10.1101/2021.05.21.21257605; this version posted May 26, 2021. The copyright holder for this preprint (which was not certified by peer review) is the author/funder, who has granted medRxiv a license to display the preprint in perpetuity.

All rights reserved. No reuse allowed without permission.

164 OD was present. Visual field testing, notable for excessive fixation losses OS and false negatives

165 OU, showed inferior altitudinal defects OD $>$ OS (figure 2A, F; insets). Fundus exam was notable

166 for bilateral pallid optic disc oedema and nasal optic disc hemorrhage in the left eye (figure 2A,

167 F). FA demonstrated focal delayed choroidal filling in the inferior macula of the left eye (figure

$1682 \mathrm{G}$, red arrow). SCP and DCP segmentation of SS-OCTA en face imaging showed foveal and

169 perifoveal changes consistent with chronic macular hole in the right eye ${ }^{16}$ (figure $2 \mathrm{C}, \mathrm{D}$ ) and

170 mild nasal reductions in the SCP and DCP densities in the left eye (figure $2 \mathrm{H}, \mathrm{I}$ ). Although SS-

171 OCTA imaging did not capture the full fundus view obtained on FA, CC segmentation showed

172 an inferior region of decreased signal extending toward the fovea (figure $2 \mathrm{~J}$, red arrows). No

173 choroidal filling delay in the right eye was observed on FA or SS-OCTA (figure 2B-E).

174 The patient was started on high-dose oral prednisone with resolution of her systemic

175 symptoms. Follow-up exam 9 months later revealed stable vision without signs of active ocular

176 involvement of GCA.

178 Case 3

179 A man in his late 70s with a history of polymyalgia rheumatica (PMR) presented with a 3-day

180 history of acute, painless vision loss OD and jaw claudication. Maintenance oral prednisone for

181 his PMR had been reduced from $20 \mathrm{mg}$ to $5 \mathrm{mg}$ daily three months prior. ESR was $126 \mathrm{~mm} / \mathrm{hr}$,

182 and CRP was $6.4 \mathrm{mg} / \mathrm{L}$. Temporal artery biopsy was not obtained due to high clinical suspicion

183 for GCA. Exam revealed visual acuities of 20/300 OD and 20/20 OS, dyschromatopsia OD, and

184 a relative afferent pupillary defect OD. Automated perimetry showed a dense superior

185 paracentral defect OD and nonspecific defects OS (figure 3A, F; insets). Fundus exam was

186 significant for inferior sectoral pallid optic disc oedema with hemorrhages in the right eye and 
medRxiv preprint doi: https://doi.org/10.1101/2021.05.21.21257605; this version posted May 26, 2021. The copyright holder for this preprint (which was not certified by peer review) is the author/funder, who has granted medRxiv a license to display the preprint in perpetuity.

All rights reserved. No reuse allowed without permission.

187 optic disc oedema with superimposed nasal cotton wool spots in the left eye (figure $3 \mathrm{~A}, \mathrm{~F}$ ). FA

188 showed optic nerve leakage and areas of hypofluorescence in the inferior macula likely (figure

189 3B, G). SS-OCTA demonstrated a reduction in SCP density in the right eye likely corresponding

190 to inner retinal atrophy (figures 3C, H; blue arrows), and DCP dilation temporally in the left eye

191 (figure 3D, I; yellow asterisk). In the CC, SS-OCTA showed mildly decreased signal inferior to

192 the fovea along the inferior arcade that was apparent on FA in the right eye (figure 3B, E; red

193 arrows). Similarly, subtle decrease in SS-OCTA CC angiographic signal inferior to the fovea on

194 SS-OCTA corresponded to the area of hypofluorescence on FA (figure 3G, J; red arrows).

195 The patient was treated with intravenous methylprednisolone followed by an oral

196 prednisone taper. Visual acuity improved to 20/50 OD. Two months later, the patient had a

197 recurrence on $30 \mathrm{mg}$ of prednisone, presenting with visual loss OS, prompting an increase in oral

198 prednisone.

199

200 GCA without choroidal hypoperfusion

201 One patient without visual symptoms and biopsy-proven GCA was imaged with SS-OCTA as a

202 control (online supplementary figure 1). The patient was a woman in her 70s referred by her

203 neurologist to evaluate for ophthalmic signs suggestive of GCA in the setting of elevated

204 inflammatory markers (erythrocyte sedimentation rate (ESR) $65 \mathrm{~mm} /$ hour and C-reactive protein

205 (CRP) $111 \mathrm{mg} / \mathrm{L}$ ), jaw claudication (confounded by active dental disease), weight loss, and

206 headaches with scalp tenderness. The patient denied visual changes. FA was obtained given her

207 atypical clinical presentation, and no choroidal filling defects were found. Subsequent right

208 temporal artery biopsy was positive, and the patient was treated with corticosteroids. 
medRxiv preprint doi: https://doi.org/10.1101/2021.05.21.21257605; this version posted May 26, 2021. The copyright holder for this preprint (which was not certified by peer review) is the author/funder, who has granted medRxiv a license to display the preprint in perpetuity.

All rights reserved. No reuse allowed without permission.

\section{DISCUSSION}

211 Choroidal filling delay demonstrated by IV dye-based angiography is a highly suggestive finding

212 of GCA in the right clinical context, due to hypoperfusion of the posterior ciliary arteries. ${ }^{6}$ As

213 such, FA serves as a useful ancillary tool in the evaluation of GCA, particularly in mild cases. To

214 our knowledge, this is the first clinical series applying SS-OCTA to image choroidal perfusion

215 abnormalities in GCA. Among eyes with delayed or incomplete perfusion defects on FA, SS-

216 OCTA showed decreased signal in the $\mathrm{CC}$ in all cases (5/5 eyes). Spatial mapping of choroidal

217 hypoperfusion with SS-OCTA matched that delineated by FA with high fidelity. Among cases

218 without choroidal filling abnormality on FA, 3/3 eyes showed no choroidal signal abnormalities

219 on SS-OCTA. In 2 eyes with choroidal hypoperfusion, SS-OCTA showed dilation of the

220 overlying deep retinal capillary plexus in a similar distribution (figures 1I, 3F). Thus, our results

221 support comparability between FA and SS-OCTA to detect choroidal hypoperfusion secondary

222 to GCA.

223 Prior studies using SD-OCTA have failed to show clear choroidal perfusion

224 abnormalities that were correspondingly evident on dye-based angiography. ${ }^{10,11}$ We previously

225 reported 4 GCA cases in which SD-OCTA demonstrated superficial peripapillary dilation and

226 retinal capillary perfusion defects that corresponded to visual field loss in the acute phase. ${ }^{10}$ Two

227 patients in the series had choroidal perfusion abnormalities evident on FA, yet SD-OCTA

228 analysis of the choroid and CC (performed on the same day as FA) showed no signal

229 abnormality in those corresponding regions. Balducci et al. reported a single case of GCA in

230 which SD-OCTA was reported to demonstrate a sectoral peripapillary choroidal perfusion defect

231 with correspondence on FA. ${ }^{11}$ However, the region in question corresponded to the perfusion bed

232 of a cilioretinal artery, which was hypoperfused, likely edematous and imparted a blockage 
medRxiv preprint doi: https://doi.org/10.1101/2021.05.21.21257605; this version posted May 26, 2021. The copyright holder for this preprint (which was not certified by peer review) is the author/funder, who has granted medRxiv a license to display the preprint in perpetuity.

All rights reserved. No reuse allowed without permission.

233 effect on both FA and SD-OCTA. Nemiroff et al. reported a case of GCA with decreased CC

234 vessel density in a triangular distribution on SD-OCTA that co-localized to a large Amalric

235 infarct on $\mathrm{FA}^{17,18}$. Amalric infarcts are notably on the more severe end of the spectrum. Our

236 present series includes cases on the milder end of the spectrum, which nonetheless manifested as

237 decreased focal choroidal perfusion on segmentation of the CC on SS-OCTA.

238 Our findings support our hypothesis that SS-OCTA offers improved resolution of deeper

239 retinal and choroidal vessels as compared to SD-OCTA and thus might be better suited to

240 capture alterations in choroidal perfusion. ${ }^{19}$ Comparative studies have demonstrated improved

241 visualization of the choroid attributed to enhanced choroidal penetration using SS-OCTA

242 compared to SD-OCTA in eyes with clinically significant cataract and AMD. ${ }^{20,21}$ In addition,

243 SS-OCTA has demonstrated greater accuracy in detecting CC flow impairment under drusen and

244 visualizing the macula in gas-filled eyes post-vitrectomy for macular holes and retinal

245 detachment. ${ }^{22,23}$ Tran et al. reported the first definitive case of choroidal hypoperfusion

246 secondary to GCA imaged using SS-OCTA to offer a direct comparison with FA and ICG. ${ }^{12}$ The $^{2}$

247 case depicted a large and dense, Amalric choroidal infarct that is most similar to the right eye of

248 case 1 depicted here (figure 2A-E). Of note, the case depicted in Tran et al. employed a different

249 SS-OCTA device (Plex-Elite 9000, Carl Zeiss Meditec, Dublin, CA) than the one used in our

250 study and allowed for direct OCTA imaging of the full choroid. While their findings are similar

251 to our findings in case 1, there are likely to be differences between SS-OCTA devices that

252 influence sensitivity in detecting subretinal perfusion abnormalities.

253 OCTA has the potential to serve as a practical alternative to FA. There are several

254 barriers and limitations to obtaining FA testing, including the need for a licensed practitioner to

255 place an IV and administer fluorescein, the longer time required to complete the test, adverse 
medRxiv preprint doi: https://doi.org/10.1101/2021.05.21.21257605; this version posted May 26, 2021. The copyright holder for this preprint (which was not certified by peer review) is the author/funder, who has granted medRxiv a license to display the preprint in perpetuity.

All rights reserved. No reuse allowed without permission.

256 reactions to fluorescein dye, $\%),{ }^{24}$ and the inability to repeat FA testing in the event of poor

257 image quality until the dye is excreted. On the other hand, OCTA is fast, easy to capture and

258 non-invasive. ${ }^{7}$ Thus, OCTA may enable more expedient assessment of choroidal perfusion than

259 dye-based angiography to facilitate the diagnosis and treatment of GCA in select cases.

OCTA provides higher resolution and laminar segmentation as compared with FA,

261 allowing for the detection of lamina-specific changes that might otherwise be obscured or not

262 appreciable on 2D FA. Segmentation of the SCP on SS-OCTA showed early reductions in

263 vascular density that corresponded with visual defects on clinical examination and automated

264 perimetry (figure 4C). ${ }^{10}$ In the DCP, we observed increased angiographic signal overlying areas

265 of choroidal hypoperfusion in 1 of 5 GCA eyes with choroidal perfusion abnormalities. It is

266 unclear what this increase in angiographic signal represents. Retinal vessels lack autonomic

267 innervation and rely on autoregulation based on local factors to maintain perfusion. ${ }^{25}$ While

268 choroidal perfusion changes have been implicated in retinal dysfunction in glaucoma, diabetes,

269 hypertension, and AMD,${ }^{26}$ outer retinal abnormalities associated with choroidal infarcts in GCA

270 have been reported, ${ }^{27}$ but the effect of choroidal changes on the retinal capillary plexuses in acute

271 GCA remains unclear. Specifically, further work is needed to determine the geographical

272 correspondence between DCP and CC changes. Finally, OCTA allows for more accurate

273 distinction of true perfusion abnormalities from artifacts (such as blockage artifacts) through

274 assessment of signal abnormalities across lamina. ${ }^{10}$ Thus, laminar segmentation affords several

275 advantages of OCTA over FA.

276 FA and SS-OCTA share some limitations. The absence of choroidal perfusion

277 abnormalities does not rule out GCA regardless of the imaging modality used (e.g., see GCA

278 control; figure 1A-J). Choroidal hypoperfusion, whether captured on FA or SS-OCTA, is not 
medRxiv preprint doi: https://doi.org/10.1101/2021.05.21.21257605; this version posted May 26, 2021. The copyright holder for this preprint (which was not certified by peer review) is the author/funder, who has granted medRxiv a license to display the preprint in perpetuity.

All rights reserved. No reuse allowed without permission.

279 specific to GCA and has been reported in AMD, CSC, diabetic retinopathy, acute posterior

280 multifocal placoid pigment epitheliopathy, and retinitis pigmentosa. ${ }^{28-32}$ As is the case with FA,

281 choroidal perfusion abnormalities suggested by OCTA must be interpreted as part of a complete

282 clinical evaluation for GCA. Ambiguous OCTA findings could be corroborated by FA and vice

283 versa.

284 Our study is limited by a relatively small number of total affected eyes. However, it is

285 worth noting that each case can be considered separately since within-subject comparisons

286 demonstrate remarkable spatial fidelity across a range of hypoperfusion severities. Our study

287 approach was qualitative, and therefore identification and assessment of signal abnormalities on

288 SS-OCTA may be subject to confirmation bias, just as they are in ambiguous cases imaged by

289 FA. Unlike FA, SS-OCTA is amenable to automated quantification that may increase the

290 sensitivity to detect more subtle perfusion abnormalities. Further study and efforts to automate

291 detection of angiographic signal changes in ischemic neuro-ophthalmic disease would be of great

292 benefit. Finally, we could not make a direct comparison between SD-OCTA and SS-OCTA

293 because GCA cases presenting to our service were imaged with one modality or the other.

294 However, cases showing areas of hypoperfusion were comparable in size and density between

295 our prior study ${ }^{10}$ and this study, thus supporting greater sensitivity of SS-OCTA.

296 In conclusion, we demonstrate high comparability between SS-OCTA and FA in

297 detecting choroidal ischemia in GCA. There are many advantages of SS-OCTA over FA,

298 including ease and expedience of obtaining imaging in the acute setting that is highly relevant in

299 clinical scenarios of suspected GCA. Further study is needed to evaluate SS-OCTA as a

300 diagnostic tool in screening for choroidal perfusion abnormalities when GCA is suspected. 
medRxiv preprint doi: https://doi.org/10.1101/2021.05.21.21257605; this version posted May 26, 2021. The copyright holder for this preprint (which was not certified by peer review) is the author/funder, who has granted medRxiv a license to display the preprint in perpetuity.

\section{REFERENCES}

1. Tehrani R, Ostrowski RA, Hariman R, Jay WM. Giant cell arteritis. Semin Ophthalmol. 2008;23(2):99-110. doi:10.1080/08820530801888097

2. Liu GT, Glaser JS, Schatz NJ, Smith JL. Visual morbidity in giant cell arteritis. Clinical

4. Hayreh SS, Podhajsky PA, Zimmerman B. Ocular manifestations of giant cell arteritis. Am J

5. Mack HG, O'Day J, Currie JN. Delayed choroidal perfusion in giant cell arteritis. J Clin Neuroophthalmol. 1991;11(4):221-227.

6. Siatkowski RM, Gass JD, Glaser JS, Smith JL, Schatz NJ, Schiffman J. Fluorescein angiography in the diagnosis of giant cell arteritis. Am J Ophthalmol. 1993;115(1):57-63. doi:10.1016/s0002-9394(14)73525-1

7. Spaide RF, Fujimoto JG, Waheed NK, Sadda SR, Staurenghi G. Optical coherence tomography angiography. Prog Retin Eye Res. 2018;64:1-55. doi:10.1016/j.preteyeres.2017.11.003

8. Spaide RF, Klancnik JM, Cooney MJ. Retinal vascular layers imaged by fluorescein angiography and optical coherence tomography angiography. JAMA Ophthalmol. 2015;133(1):45-50. doi:10.1001/jamaophthalmol.2014.3616

9. Borrelli E, Sarraf D, Freund KB, Sadda SR. OCT angiography and evaluation of the choroid and choroidal vascular disorders. Prog Retin Eye Res. 2018;67:30-55. doi:10.1016/j.preteyeres.2018.07.002

10. Gaier ED, Gilbert AL, Cestari DM, Miller JB. Optical coherence tomographic angiography identifies peripapillary microvascular dilation and focal non-perfusion in giant cell arteritis. Br J Ophthalmol. 2018;102(8):1141-1146. doi:10.1136/bjophthalmol-2017-310718

11. Balducci N, Morara M, Veronese C, et al. Optical coherence tomography angiography in acute arteritic and non-arteritic anterior ischemic optic neuropathy. Graefes Arch Clin Exp Ophthalmol. 2017;255(11):2255-2261. doi:10.1007/s00417-017-3774-y

12. Tran AQ, Yannuzzi NA, Motulsky EH, et al. Swept-Source Optical Coherence Tomography Angiography of an Amalric Choroidal Infarction in a Rare Presentation of Giant Cell Arteritis With Bilateral Corneal Edema. Ophthalmic Surg Lasers Imaging Retina. 2018;49(10):e157-e160. doi:10.3928/23258160-20181002-21 
medRxiv preprint doi: https://doi.org/10.1101/2021.05.21.21257605; this version posted May 26, 2021. The copyright holder for this preprint (which was not certified by peer review) is the author/funder, who has granted medRxiv a license to display the preprint in perpetuity. All rights reserved. No reuse allowed without permission.

13. Unterhuber A, Povazay B, Hermann B, Sattmann H, Chavez-Pirson A, Drexler W. In vivo retinal optical coherence tomography at $1040 \mathrm{~nm}$ - enhanced penetration into the choroid. Opt Express. 2005;13(9):3252-3258. doi:10.1364/opex.13.003252

14. Povazay B, Bizheva K, Hermann B, et al. Enhanced visualization of choroidal vessels using ultrahigh resolution ophthalmic OCT at $1050 \mathrm{~nm}$. Opt Express. 2003;11(17):1980-1986. doi:10.1364/oe.11.001980

15. Miller AR, Roisman L, Zhang Q, et al. Comparison Between Spectral-Domain and SweptSource Optical Coherence Tomography Angiographic Imaging of Choroidal Neovascularization. Invest Ophthalmol Vis Sci. 2017;58(3):1499-1505. doi:10.1167/iovs.16-20969

16. Michalewska Z, Nawrocki J. Swept-Source OCT Angiography of Full-Thickness Macular Holes: Appearance and Artifacts. Ophthalmic Surg Lasers Imaging Retina. 2018;49(2):111121. doi:10.3928/23258160-20180129-05

17. Nemiroff J, Phasukkijwatana N, Vaclavik V, Nagiel A, Holz ER, Sarraf D. THE SPECTRUM OF AMALRIC TRIANGULAR CHOROIDAL INFARCTION. Retin Cases Brief Rep. 2017;11 Suppl 1:S113-S120. doi:10.1097/ICB.0000000000000442

18. Amalric P. Acute choroidal ischemia. Trans Ophthalmol Soc U K. 1971;91:305-322.

19. Laíns I, Wang JC, Cui Y, et al. Retinal applications of swept source optical coherence tomography (OCT) and optical coherence tomography angiography (OCTA). Prog Retin Eye Res. Published online January 28, 2021:100951. doi:10.1016/j.preteyeres.2021.100951

20. Povazay B, Hermann B, Unterhuber A, et al. Three-dimensional optical coherence tomography at $1050 \mathrm{~nm}$ versus $800 \mathrm{~nm}$ in retinal pathologies: enhanced performance and choroidal penetration in cataract patients. J Biomed Opt. 2007;12(4):041211. doi:10.1117/1.2773728

21. Cicinelli MV, Cavalleri M, Consorte AC, et al. SWEPT-SOURCE AND SPECTRAL DOMAIN OPTICAL COHERENCE TOMOGRAPHY ANGIOGRAPHY VERSUS DYE ANGIOGRAPHY IN THE MEASUREMENT OF TYPE 1 NEOVASCULARIZATION. Retina Phila Pa. 2020;40(3):499-506. doi:10.1097/IAE.0000000000002452

22. Lane M, Moult EM, Novais EA, et al. Visualizing the Choriocapillaris Under Drusen: Comparing 1050-nm Swept-Source Versus 840-nm Spectral-Domain Optical Coherence Tomography Angiography. Invest Ophthalmol Vis Sci. 2016;57(9):OCT585-590. doi:10.1167/iovs.15-18915

23. Ahn SJ, Park SH, Lee BR. VISUALIZATION OF THE MACULA IN GAS-FILLED EYES: Spectral Domain Optical Coherence Tomography Versus Swept-Source Optical Coherence Tomography. Retina Phila Pa. 2018;38(3):480-489. doi:10.1097/IAE.0000000000001560 
medRxiv preprint doi: https://doi.org/10.1101/2021.05.21.21257605; this version posted May 26, 2021. The copyright holder for this preprint (which was not certified by peer review) is the author/funder, who has granted medRxiv a license to display the preprint in perpetuity.

All rights reserved. No reuse allowed without permission.

24. Kornblau IS, El-Annan JF. Adverse reactions to fluorescein angiography: A comprehensive review of the literature. Surv Ophthalmol. 2019;64(5):679-693. doi:10.1016/j.survophthal.2019.02.004

25. Delaey C, Van De Voorde J. Regulatory mechanisms in the retinal and choroidal circulation. Ophthalmic Res. 2000;32(6):249-256. doi:10.1159/000055622

26. Reiner A, Fitzgerald MEC, Del Mar N, Li C. Neural control of choroidal blood flow. Prog Retin Eye Res. 2018;64:96-130. doi:10.1016/j.preteyeres.2017.12.001

27. Garrity ST, Holz EJ, Sarraf D. Amalric Triangular Syndrome Associated With Outer Nuclear Layer Infarction. Ophthalmic Surg Lasers Imaging Retina. 2017;48(8):668-670. doi:10.3928/23258160-20170802-10

28. Borrelli E, Shi Y, Uji A, et al. Topographic Analysis of the Choriocapillaris in Intermediate Age-related Macular Degeneration. Am J Ophthalmol. 2018;196:34-43. doi:10.1016/j.ajo.2018.08.014

29. Teussink MM, Breukink MB, van Grinsven MJJP, et al. OCT Angiography Compared to Fluorescein and Indocyanine Green Angiography in Chronic Central Serous Chorioretinopathy. Invest Ophthalmol Vis Sci. 2015;56(9):5229-5237. doi:10.1167/iovs.1517140

30. Nesper PL, Roberts PK, Onishi AC, et al. Quantifying Microvascular Abnormalities With Increasing Severity of Diabetic Retinopathy Using Optical Coherence Tomography Angiography. Invest Ophthalmol Vis Sci. 2017;58(6):BIO307-BIO315. doi:10.1167/iovs.17-21787

31. Burke TR, Chu CJ, Salvatore S, et al. Application of OCT-angiography to characterise the evolution of chorioretinal lesions in acute posterior multifocal placoid pigment epitheliopathy. Eye Lond Engl. 2017;31(10):1399-1408. doi:10.1038/eye.2017.180

32. Toto L, Borrelli E, Mastropasqua R, et al. Macular Features in Retinitis Pigmentosa: Correlations Among Ganglion Cell Complex Thickness, Capillary Density, and Macular Function. Invest Ophthalmol Vis Sci. 2016;57(14):6360-6366. doi:10.1167/iovs.16-20544 
TABLES

Table 1. Patient characteristics and summary of fluorescein angiography (FA) and swept-source optical coherence tomographic angiography (SS-OCTA) findings.

\begin{tabular}{|c|c|c|c|c|c|c|c|c|}
\hline Case & $\begin{array}{l}\text { Age } \\
\text { Range } \\
\text { (years) }\end{array}$ & Sex & $\begin{array}{c}\text { ESR } \\
(\mathrm{mm} / \mathrm{hr})\end{array}$ & Laterality & $\begin{array}{c}\text { Temporal } \\
\text { artery } \\
\text { biopsy }\end{array}$ & BCVA & $\begin{array}{c}\text { DELAYED } \\
\text { CHOROIDAL } \\
\text { PERFUSION } \\
\text { ON FA }\end{array}$ & $\begin{array}{c}\text { DELAYED } \\
\text { CHOROIDAL } \\
\text { PERFUSION } \\
\text { ON } \\
\text { SS-OCTA }\end{array}$ \\
\hline \multirow[t]{2}{*}{1} & \multirow[t]{2}{*}{$\begin{array}{l}75-80 \\
\end{array}$} & \multirow[t]{2}{*}{ F } & \multirow[t]{2}{*}{119} & OD & + & $\mathrm{CF}$ & Yes & Yes \\
\hline & & & & OS & N/A & \begin{tabular}{|l|}
$20 / 30$ \\
\end{tabular} & Yes & Yes \\
\hline \multirow[t]{2}{*}{2} & \multirow[t]{2}{*}{$90-95$} & \multirow[t]{2}{*}{ F } & \multirow[t]{2}{*}{117} & OD & + & CF* & No & No \\
\hline & & & & OS & + & $20 / 30$ & Yes & Yes \\
\hline \multirow[t]{2}{*}{3} & \multirow[t]{2}{*}{$75-80$} & \multirow[t]{2}{*}{$\mathrm{M}$} & \multirow[t]{2}{*}{113} & OD & N/A & $20 / 300$ & Yes & Yes \\
\hline & & & & OS & N/A & $20 / 20$ & Yes & Yes \\
\hline \multirow[t]{2}{*}{ Control } & \multirow[t]{2}{*}{$70-75$} & \multirow[t]{2}{*}{$\mathrm{F}$} & \multirow[t]{2}{*}{65} & OD & + & $20 / 20$ & No & No \\
\hline & & & & OS & N/A & $20 / 15$ & No & No \\
\hline
\end{tabular}

*Baseline BCVA was CF vision from chronic macular hole. 
medRxiv preprint doi: https://doi.org/10.1101/2021.05.21.21257605; this version posted May 26, 2021. The copyright holder for this preprint (which was not certified by peer review) is the author/funder, who has granted medRxiv a license to display the preprint in perpetuity.

All rights reserved. No reuse allowed without permission.

\section{FIGURE LEGENDS}

414 Figure 1. Case 1: A woman in her 70s with GCA causing sudden vision loss OD. Fundus images

415 of the right (A) and left (F) eyes. Automated (Humphrey) perimetry (30-2) of the left eyes (F;

416 inset). FA images taken in the mid-phase (1:21) and early phase (0:25) for the right (B) and left

417 (G) eyes, respectively. En face SS-OCTA 6x6 mm images with laminar segmentation of the

418 superficial capillary plexus $(C, H)$, deep capillary plexus $(D, I)$ and choriocapillaris $(E, J)$ for the

419 right and left eyes, respectively. Insets depict B-scan images through the fovea with segmented

420 area highlighted in blue. Red arrows outline matching boundaries of perfusion/nonperfusion on

421 FA and SS-OCTA. Green arrows indicate decreased angiographic signal in the perfusion beds of

422 small cilioretinal arteries. Yellow arrows denote areas of DCP dilation.

424 Figure 2. Case 2: A woman in her 90s with chronic macular hole in the right eye and systemic

425 symptoms of GCA. Fundus images of the right (A) and left (F) optic discs. Automated

426 (Humphrey) perimetry (24-2) of the right and left eyes (A, F; insets). FA images taken in the

427 mid-phase (1:02) and early phase (0:38) for the right (B) and left (G) eyes, respectively. En face

428 SS-OCTA $4.5 \times 4.5 \mathrm{~mm}$ images with laminar segmentation of the superficial capillary plexus (C,

$429 \mathrm{H})$, deep capillary plexus (D, I) and choriocapillaris (E, J) for the right and left eyes,

430 respectively. Insets depict B-scan images through the fovea with segmented area highlighted in

431 blue. Red arrows indicate areas of hypoperfusion on FA and SS-OCTA. In (C) and (D), the

432 bright signal in the centre is due to incorrect segmentation of the macular hole by the software

433 algorithm.

434

435 Figure 3. Case 3: A man in his 70s with vision loss OD. Fundus images of the right (A) and left 
medRxiv preprint doi: https://doi.org/10.1101/2021.05.21.21257605; this version posted May 26, 2021. The copyright holder for this preprint (which was not certified by peer review) is the author/funder, who has granted medRxiv a license to display the preprint in perpetuity.

All rights reserved. No reuse allowed without permission.

436 (F) optic discs. Automated (Humphrey) perimetry (24-2) of the right and left eyes (A, F; insets).

437 FA images taken in the mid-phase (1:09; 2:24) for the right (B) and left (G) eyes, respectively.

438 En face SS-OCTA $6 \times 6 \mathrm{~mm}$ images with laminar segmentation of the superficial capillary plexus

$439(\mathrm{C}, \mathrm{H})$, deep capillary plexus $(\mathrm{D}, \mathrm{I})$ and choriocapillaris $(\mathrm{E}, \mathrm{J})$ for the right and left eyes,

440 respectively. Insets depict B-scan images through the fovea with segmented area highlighted in

441 blue. Red arrows indicate areas of hypoperfusion on FA and SS-OCTA. Blue arrows indicate

442 decreased angiographic signal on SS-OCTA likely due to inner retinal atrophy. Yellow asterisk

443 denotes area of DCP dilation.

445 Online supplementary figure 1. Swept-source optical coherence tomographic angiography (SS-

446 OCTA) images from a control, GCA-positive patient in her 70s without ocular involvement.

447 Fundus images of the right (A) and left (F) eyes. Fluorescein angiography (FA) images taken in

448 the early phase (0:17) and mid-phase (0:46) for the right (B) and left (G) eyes, respectively. En

449 face SS-OCTA 6x6 mm images with laminar segmentation of the superficial capillary plexus (C,

$450 \mathrm{H})$, deep capillary plexus (D, I) and choriocapillaris (E, J) for the right and left eyes,

451 respectively. Horizontal lines on SS-OCTA images are due to motion artifact. 


\section{Figure 1}

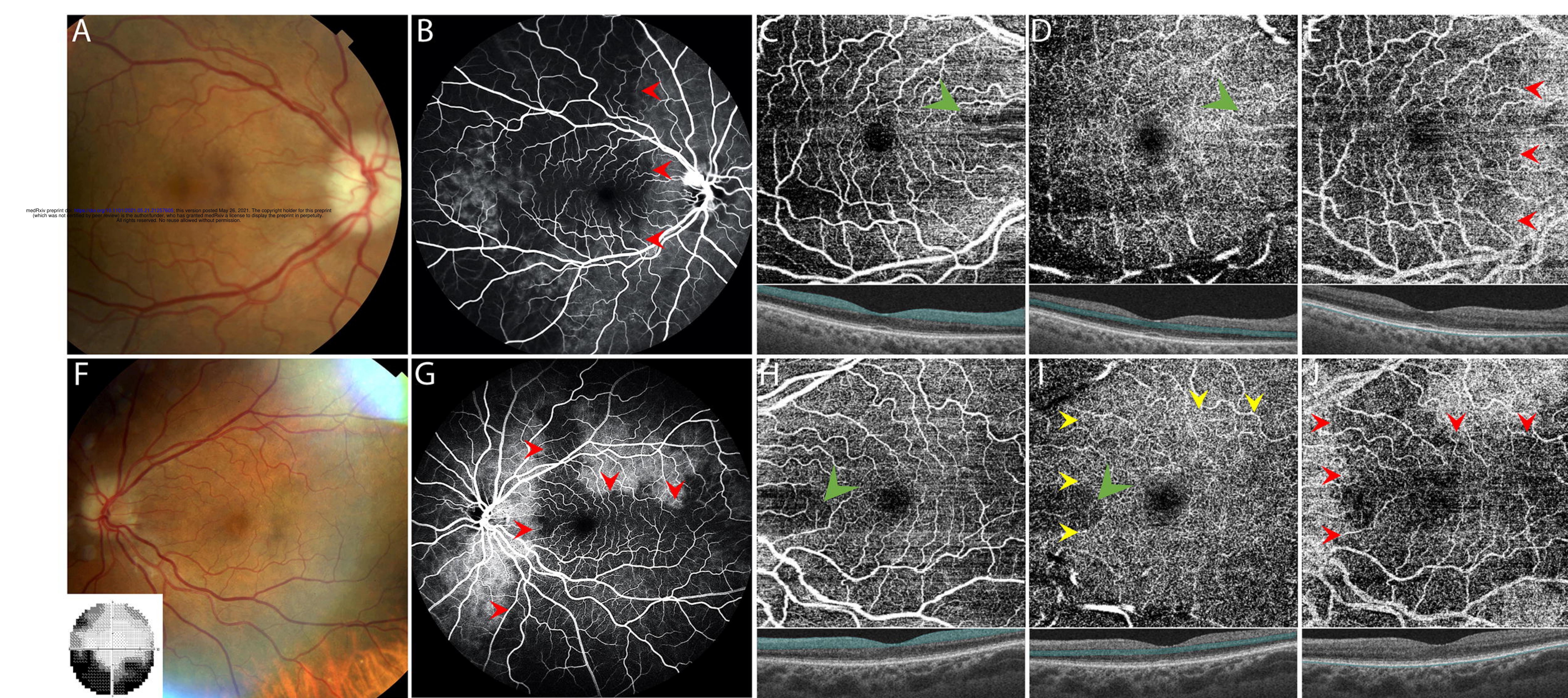




\section{Figure 2}

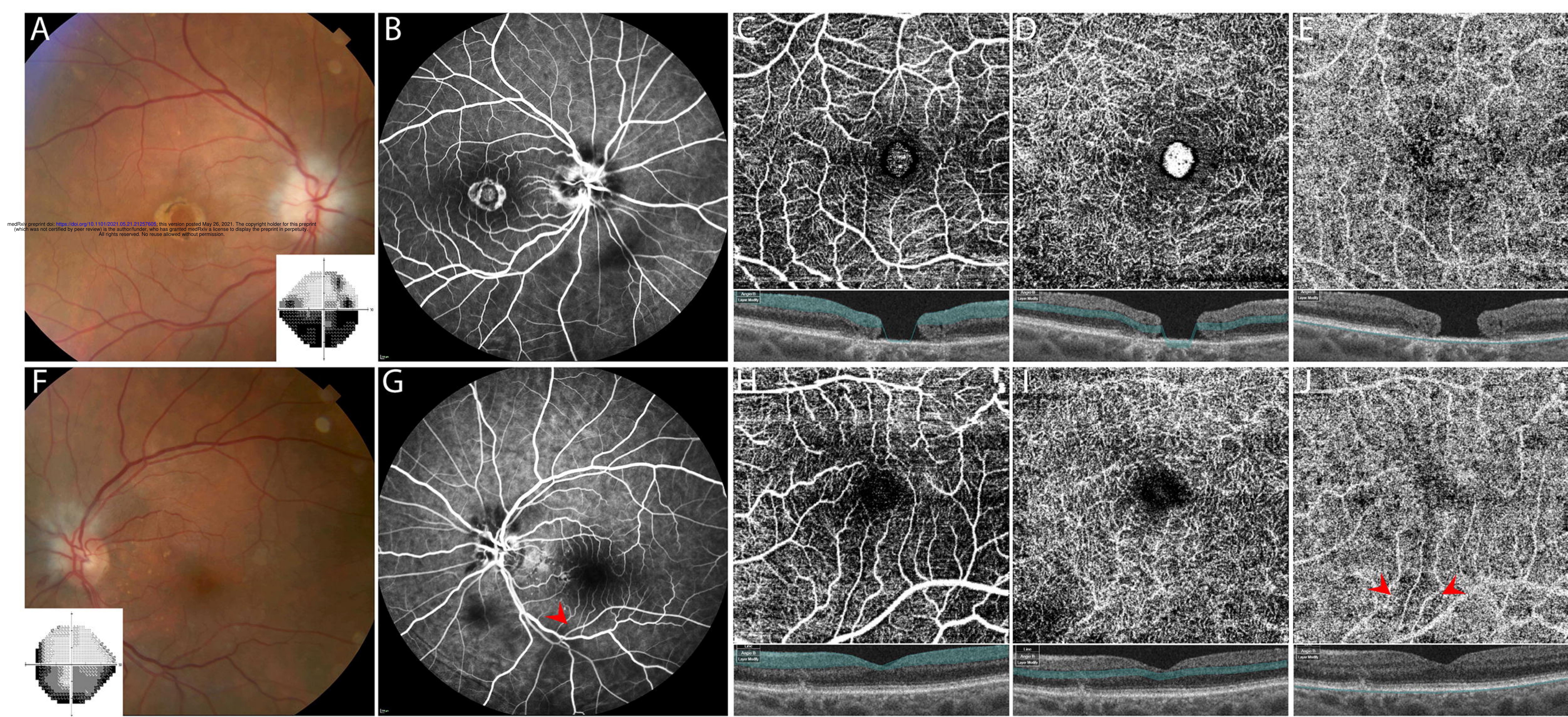


Figure 3

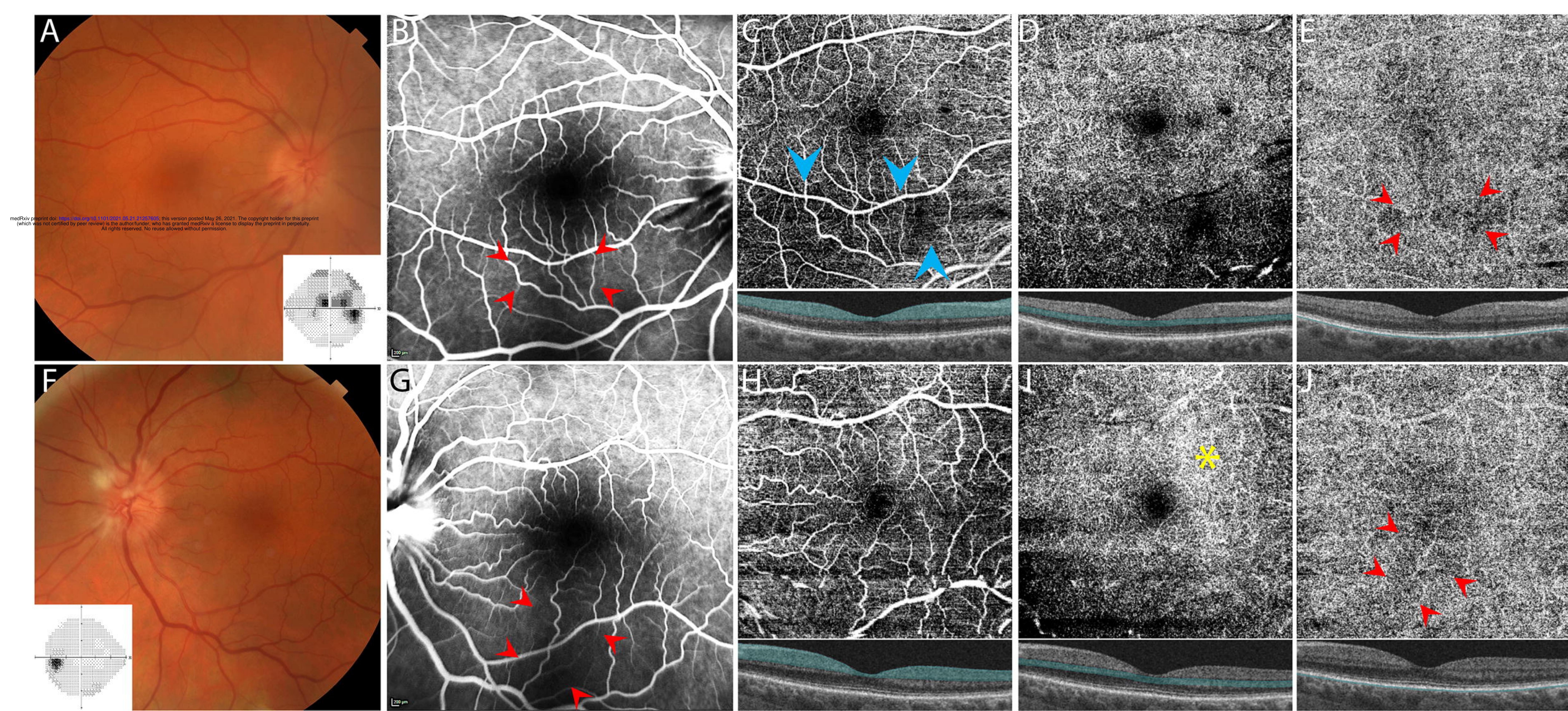

